\title{
The impact of three mealybug species on life table parameters of vedalia beetle, Rodolia cardinalis (Mulsant) (Coleoptera: Coccinellidae).
}

\author{
Ghada S. Mohamed
}

Plant Protection Department, Faculty of Agriculture, South Valley University, Qena, Egypt.

\begin{abstract}
This study aimed to measure survivorship and fecundity of the vedalia beetle, Rodolia cardinalis (Mulsant) reared on three mealybug species (Icerya purchasi Maskell, Planococcus ficus (Signoret) and Pseudococcus longispinus (Targioni-Tozzetti)). The experiment was conducted under laboratory conditions, life table and population parameters were established to evaluate survivorship in all stages of the vedalia beetle life cycle. Results obtained from this experiment showed that the highest rates of death were recorded in the immature stages (larval stages) for all prey was $42.86,45,44.11 \%$ and the total mortality was 57.69, 62.11, and $50 \%$ on I. purchasi, P. ficus and P. longispinus respectively. Fertility tables recorded that the reproductive rate $\mathrm{R}_{0}$ of the population was $139.98,81.10,37.70$ and mean generation time $\mathrm{T}$ was $35.85,44.71,44.03$ and the intrinsic rate of increase $\mathrm{r}$ was $0.14,0.09,0.08$ and the population doubling time $\mathrm{D}_{\mathrm{T}}$ was within 4.95, 6.93,8.66 day for three mealybug species respectively. Based on the mentioned results, it could be proved that the survivorship curve of Rodolia cardinalis (Mulsant) belongs to a diagonal model curve, which indicates a humble rate of death during life stages and piecemeal reduction when moving toward adulthood with a significant influence of nutrition preference for $I$. purchasi comparative with $P$. ficus and $P$. longispinus.
\end{abstract}

Keywords: vedalia beetle, Rodolia cardinalis, life table, fecundity parameters.

\section{Introduction}

Coccinellid predator considered an important predatory insect. It was registered in different regions of the world on many agricultural crops of economic value. Significant species of it play an important role in biological control of aphid species, whiteflies, and other soft scale insects. $\quad R$. cardinalis (Coleoptera:

\section{*Corresponding author; Ghada S. Mohamed}

Email: d.ghada1@yahoo.com

Received: August 21, 2020;

Accepted: September 17, 2020;

Published: September 21, 2020.
Coccinellidae) is the main Coccinellid predator devouring on mealybug species

(Awadalla 2010). It has been announced to be an extremely active naturalistic enemy of mealybug pests in view of the fact that both larvae and adults insects mainly depends on feeding on these pests (Ozgokce et al., 2006). These species of predators have also been successfully reared and released on citrus trees and grape vineyards, in addition to glasshouses which mealybugs considered the main insect pest (Ozgokce et al., 2006). In Egypt, 
mealybugs species considered one of the most serious pests that infested citrus, guava, grapes and many ornamental plants. Icerya purchasi Maskell, Planococcus ficus (Signoret) and Pseudococcus longispinus (Targioni-Tozzetti) are important pests in many parts of the world, especially in the tropical and subtropical regions. The great harm of these pests is attributed to the weak effect of natural enemies which could decrease their numbers (Abd Rabou, 2001; Abdel-Salam et al., 2010; Mohamed, 2013).

Mealy bugs cause huge losses to farmers due to feeding these insects on the tissues of plants by absorbing their saps and injecting toxins, and more than that, these insects are a vector of many plant viruses. In addition, these insects excreted their excreta as honeydew, which is a sirup of sugar liquid that covered leaves them with a glossy, gummy layer. Honeydew considered a fertile nutritional environment for the reproduction of black mold fungi that negatively affects the process of photosynthesis that also destroys the plant's manifestation. Severe plant infestation by mealybugs may cause the leaves to fall off, and It may lead to the death of whole plants if they are not controlled at appropriate times (Esfandiari and Mossadegh, 2007).

In Egypt, little information was obtainable on the effectiveness of various prey species on the biological attributes and life table guidelines of the most substantial predators attacking mealybug species. However, few studies have been concerned with the developmental time, consuming rate, life span and fertility of this predator to evaluate these measurements for breeding methods and release (Ragab, 1995 and Saleh et al., 2017). Therefore, the objective of this investigation aimed to highlight and clarify the importance of studying the effect of mealybug species on the biological attributes of vedalia beetle predator $R$. cardinalis under laboratory stipulation to control the mealybug species because of its high propagation rate and fast growth. The results obtained were anticipated to supply beneficial recommendations about its futurity use as a biocontrol factor in mealybug management.

\section{Materials and Methods}

\section{Insects}

The colony of vedalia beetle, $R$. cardinalis was established in rearing jars by feeding on the long-tailed, $P$. longispinus under laboratory controlling (temperature of $26 \pm 2{ }^{\circ} \mathrm{C}$ and $60 \pm$ $5 \%$ relative humidity) in the Plant Protection Department, Faculty of Agriculture, South Valley University. Australian mealybug $I$. purchasi was originally collected from Pittosporum tobira (Thunb.) plants; $P$. longispinus was originally collected on Acalypha marginata plants from the Agricultural Research Experiments Center, Faculty of Agriculture, Assiut University. Whereas the vine mealybugs, P. ficus was originally collected on grapevine plants from the Agricultural Research Experiments Center, Faculty of Agriculture, South Valley University.The populations of the mealybugs (I. purchasi, P. ficus and P. longispinus) were reared on potato sprouts at the laboratory conditions.

\section{Development and survivorship of $R$. cardinalis immatures}

$R$. cardinalis adults that were reared on the long-tailed, $P$. longispinus were confined in the petri dish $(9 \times 1.5 \mathrm{~cm})$, accompanied by nymphs third age of mealybug as a prey feeding on it in Petri dishes lined with filter paper till the eggs of $R$. cardinalis were put. In a random way, one egg was captured, for development, while the $R$. cardinal adults and the other remaining eggs were removed. Every 24 hours, the survival and development of eggs and larvae of the vedalia beetle are observed using a stereomicroscope 
(7x-45x OPTO-EDU A23.1502-T1, Beijing, China) of 10-60 magnification power. On each type of mealybug, thirty eggs of $R$. cardinalis were breeding. Bearing in mind, the mealybugs change every three days to ensure they are supplied with fresh food.

\section{Fecundity and longevity of $R$. cardinalis adults}

One newlywed adult pair of $R$. cardinalis was bred in a Petri dish $(9 \times 1.5 \mathrm{~cm})$ and each of them was fed with one of the three types of mealybugs, which are changed daily to make sure they are fresh. The eggs laid by the female of $R$. cardinalis were recorded and counted daily. Also, the fertility and life span of the $R$. cardinalis female adults were accounted for. Ten female adults of $R$. cardinalis raised on each separated species of mealybug were noticed.

Life table analysis

Based on the arithmetic methods used by Southwood (1966), life table coefficients were calculated for $R$. cardinalis fed on the three types of mealybugs (I. purchasi, P. ficus and P. longispinus). The results obtained for the survival and reproduction were used to calculate, $\mathrm{x}=$ (the age category), $\mathrm{lx}$ (The number of survivors at the beginning of each age group), Lx: The number of living individuals through age $\mathrm{x}$ and $\mathrm{x}+1, \mathrm{Lx}=(\mathrm{lx}+$ $1 x+1) 1 / 2, d x$ : The number of individuals who died during the age stage $x, 100 q x$ : The percentage of deaths visible in individuals, 100qx $=(\mathrm{dx} / \mathrm{lx}) 100, \mathrm{Sx}$ : The rate of individuals who survive in the stage, Tx: The total number of individuals in each age $x$ Units after the age $\mathrm{x}$, ex: Average life expectancy for individuals of age $\mathrm{x}, \mathrm{ex}=\mathrm{Tx} / \mathrm{lx}$ and $\mathrm{mx}$ (The fertility rate for each female). Final reproduction value $\left(\mathrm{R}_{0}\right)$ $=\sum \mathrm{lx} \mathrm{mx}$, Generation length rate $(\mathrm{T})=\sum \mathrm{x} 1 \mathrm{x}$ $\mathrm{mx} / \mathrm{Ro}$, The time needed to double the population $(D T)=\log _{\mathrm{e}} 2 / \mathrm{r}$, The fundamental rate of increase $(r)=\log _{e} R_{o} / T$, Limited rate of increase $(\lambda)=\mathrm{e}^{\mathrm{r}}$.

\section{Results and Discussion}

There is great difficulty in controlling adult insects of mealybugs species due to the heavy wax excretion that coating these bodies. Based on that result, most of the pesticides that were used to control and reduce the populations of these pests targeted the immature stages. (Townsend et al., 2000). The modern direction to dominance the mealybug utilizing biological factors management. Insect predators are immediately applied as significant biotic elements to control many species of mealybug in numerous regions (Afifi et al., 2010). In Egypt, the vedalia beetle, $R$. cardinalis is considered one of the vital biological control elements of many species of mealybugs (Ghanim et al. 2006; Awadalla, 2010).

As a matter of fact, scientists study life tables as a way to estimate population growth as well as to predict the size of the population increase. Life tables provide detailed information on the stages of development, survival rates for each age, fertility, and average life expectancy of the population. (Yang et al., 2013). Laboratory studies provide important information and results on the dynamics and population of insects. However, these results may be completely incorrect in nature. Host mealybugs species are key factors for the growth and development of $R$. cardinalis; the development of $R$. cardinalis has also been considered a good indication of the viability of mealybugs as a host and benefit from it as a good source of food.

\section{Age-Specific Survival Life Table:}

The results obtained from tables (1, 2 and 3 ) showed that the high deaths from $R$. cardinalis were recorded in the larval stages, especially the early stages of them, then the deaths gradually decreased in the advanced stages of 
predator life. The first age of the larvae recorded the highest mortality rate (22.34, 16.44 and 23.08) on three mealybug species I.purchasi, P.ficus and P. longispinus respectively.

Table (1): Life table of vedalia beetle, Rodolia cardinalis on Icerya purchasi

\begin{tabular}{cccccccc}
\hline $\mathrm{x}$ & $\mathrm{l}_{\mathrm{x}}$ & $\mathrm{L}_{\mathrm{x}}$ & $\mathrm{d}_{\mathrm{x}}$ & $100_{\mathrm{qx}}$ & $\mathrm{s}_{\mathrm{x}}$ & $\mathrm{T}_{\mathrm{x}}$ & $\mathrm{e}_{\mathrm{x}}$ \\
Eggs & 130 & 117.5 & 25 & 19.23 & 80.77 & 510 & 3.92 \\
\hline $1^{\text {st }}$ larval instar & 105 & 94.5 & 21 & 22.34 & 77.66 & 392.5 & 3.74 \\
$2^{\text {nd }}$ larval instar & 84 & 78.5 & 11 & 10.48 & 89.52 & 298 & 3.55 \\
$3^{\text {rd }}$ larval instar & 73 & 70.5 & 5 & 6.85 & 93.15 & 219.5 & 3.01 \\
$4^{\text {th }}$ larval instar & 68 & 64 & 8 & 11.76 & 88.24 & 149 & 2.19 \\
pupa & 60 & 57.5 & 5 & 8.33 & 91.67 & 85 & 1.42 \\
Adults & 55 & 27.5 & & & & & \\
\hline
\end{tabular}

It may be that one of the reasons for the high number of deaths in the first age of predator larvae is the intense crowding of these small larvae on their hosts from mealybugs to obtain food. Larvae exhibit offensive behavior as a result of competition for food, which of course reduces their population. On the other hand, larval death at an early age can be attributed to the phenomenon of overfeeding, which gradually decreases with the older ages of the larvae. The death of young larvae may also be due to their strong influence by the surrounding weather factors such as heat and humidity, and this is clearly shown in field studies.

Table (2): Life table of vedalia beetle, Rodolia cardinalis on Planococcus ficus

\begin{tabular}{cccccccc}
\hline $\mathrm{x}$ & $\mathrm{l}_{\mathrm{x}}$ & $\mathrm{L}_{\mathrm{x}}$ & $\mathrm{d}_{\mathrm{x}}$ & $100_{\mathrm{qx}}$ & $\mathrm{s}_{\mathrm{x}}$ & $\mathrm{T}_{\mathrm{x}}$ & $\mathrm{e}_{\mathrm{x}}$ \\
\hline Eggs & 95 & 84 & 22 & 23.16 & 76.84 & 353.5 & 3.72 \\
$1^{\text {st }}$ larval instar & 73 & 67 & 12 & 16.44 & 83.56 & 269.5 & 3.69 \\
$2^{\text {nd }}$ larval instar & 61 & 56.5 & 9 & 14.75 & 85.25 & 202.5 & 3.32 \\
$3^{\text {rd }}$ larval instar & 52 & 45 & 8 & 15.38 & 84.62 & 146 & 2.81 \\
$4^{\text {th }}$ larval instar & 44 & 42 & 4 & 9.09 & 90.91 & 98 & 2.23 \\
pupa & 40 & 38 & 4 & 10 & 90 & 56 & 1.4 \\
Adults & 36 & 18 & & & & & \\
\hline
\end{tabular}

Table (3): Life table of vedalia beetle, Rodolia cardinalis on Pseudococcus longispinus
The results obtained are identical to the results of (Ali and Rizvi, 2009) who mentioned that the first larval instars, presented a high death-rate in comparison with the second instar than the $3^{\text {rd }}$ and $4^{\text {th }}$ instars and this is maybe due to much delicate of the $1^{\text {st }}$ instar than the later instars. While Kindlmann, et al. (2000) found that the larvae of two predatory, Harmonia axyridis and Coccinella septempunctata were demonstrated the highest mortality during the first and fourth instars. 


\begin{tabular}{lccccccc}
\hline $\mathrm{x}$ & $\mathrm{l}_{\mathrm{x}}$ & $\mathrm{L}_{\mathrm{x}}$ & $\mathrm{d}_{\mathrm{x}}$ & $100_{\mathrm{qx}}$ & $\mathrm{s}_{\mathrm{x}}$ & $\mathrm{T}_{\mathrm{x}}$ & $\mathrm{e}_{\mathrm{x}}$ \\
\hline Eggs & 90 & 84 & 12 & 13.33 & 86.67 & 384 & 4.27 \\
$1^{\text {st }}$ larval instar & 78 & 69 & 18 & 23.08 & 76.92 & 300 & 3.85 \\
$2^{\text {nd }}$ larval instar & 60 & 59 & 2 & 3.33 & 96.67 & 231 & 3.85 \\
$3^{\text {rd }}$ larval instar & 58 & 54 & 8 & 13.79 & 86.21 & 172 & 2.97 \\
$4^{\text {th }}$ larval instar & 50 & 49 & 2 & 4 & 96 & 118 & 2.36 \\
pupa & 48 & 46.5 & 3 & 6.25 & 93.75 & 69 & 1.44 \\
Adults & 48 & 22.5 & & & & & \\
\hline
\end{tabular}

Generally, the highest mortality rate was recorded in the larval stage, taking into account the length of the larval life span compared to other age stages. The results showed that the death rate in the larval stage was $42.86,45$ and $44.11 \%$ on I. purchasi, $P$. ficus and $P$. longispinus in the mentioned order. Pretty much our results agree with Baskaran et al. (2002) in Indian, When they conducted their studies on life tables of the Australian ladybird beetle, Cryptolaemus montrouzieri when bred on mealybugs (Maconellicoccus hirsutus and Dactylopius tomentosus) under laboratory conditions. The percentage of death during the larval age was recorded 43, 17, and 40.18 on Maconellicoccus hirsutus and Dactylopius tomentosus respectively. Also, there are many reasons for the high death rate in the larval age of the predator being studied, $R$. cardinalis such as Cannibalism which may clarify a substantial survival technique for numerous insect types. The ecological theorem picks out many agents that can impact cannibalism, containing sustenance accessibility, nourishment goodness, size inconsistency, the grade of closeness, and population density. Cannibalism was monitored and studied for a long time in the Coleoptera. Cannibalism or self-predation considered the most significant mortality agent for larval coccinellids Schellhorn and Andow (1999). Michaud (2003) was, studied a comparative of larval cannibalism in three species of ladybird,( Cycloneda sanguinea (Linnaeus), Harmonia axyridis (Pallas) and Olla v-nigrum (Mulsant) Coccinellidae (Coleoptera) ). Obrycki and Hiring (1998) confirmed through their studies that cannibalism is the main problem they face when raising coccinellid species for the purpose of using them in biological control programs.

During the egg stage, the death rate was recorded $19.23,23.16$ and $13.33 \%$ on three mealybug species, I. purchasi, $P$. ficus and $P$. longispinus respectively, which also expresses the proportion of hatching on the three types of mealybug species under study, taking into account the genetic and physiological factors that influence infertility. On the same line of our consequence, Results of Baskaran et al. (1999) reported that the egg stage had a death rate of $20.66 \%$ and 18.25 when studying life tables for Australian ladybird beetle, Cryptolaemus montrouzieri on Planococcus citri and Dactylopius tomentosus.

The final exit indicated by tables (1,2 and 3) indicates that the total final percentages death of vedalia beetle, $R$. cardinalis was 57.69, 62.11 and $50.00 \%$ on three mealybug species, I. purchasi, $P$. ficus and $P$. longispinus, respectively. The results of our study were consistent with the results recorded by Kairo and Murphy (1995) which 
showed that the total percentage of death of Rodolia iceryae on Icerya pattersoni was $56.00 \%$.

Figure (1) shows the survival curves (lx) of $R$. cardinalis that were raised on three mealybug species. These curves demonstrated that mortality rates were relatively high in the early stages of the life of $R$. cardinalis, and then those rates began to decline when reaching the stage adult for all mealybug species that were studied.

The results confirmed that the diagonal model curve attributed to Schowalter (2011) applies to the survival curve of $R$. cardinalis. The results also showed the significant effect of food quality on mortality rates during different stages of the life cycle. Bearing in mind the significant effect of $I$. purchasi as food for $R$. cardinalis in compared to other types of mealybug used in breeding.

The effect of food was clearly demonstrated on the ability of $R$. cardinalis to survive during different ages as $R$. cardinalis recorded the higher survival rates when fed on I. purchasi followed by $P$ longispinus, and $P$. ficus. According to the above, the I. purchase considered is the preferred food or prey for $R$. cardinalis. In this direction, there are many studies that have been conducted to know the effect of mealybug species on the growth, development, and survival of predators that feed on them, such as Cryptolaemus montrouzieri on two mealybug species, Planococcus citri and Dactylopius tomentosus Baskaran et al. (1999), Coccinella septempunctata L. and Harmonia axyridis Pallas (Coleoptera: Coccinellidae) on Aphis citricola van der Goot (Homoptera: Aphididae), and on the twospotted spider mite, Tetranychus urticae Koch (Acarina: Tetranychidae)Lucas et al. (1997).

Age-Specific fecundity table: 1x (The number of survivors at the beginning of each age group) and $m x$ (The fertility rate for each female) of the vedalia beetle, $R$. cardinalis reared on three mealybug species $I$. purchasi, $P$. ficus and $P$. longispinus are shown on a comprehensive data in figure (2).

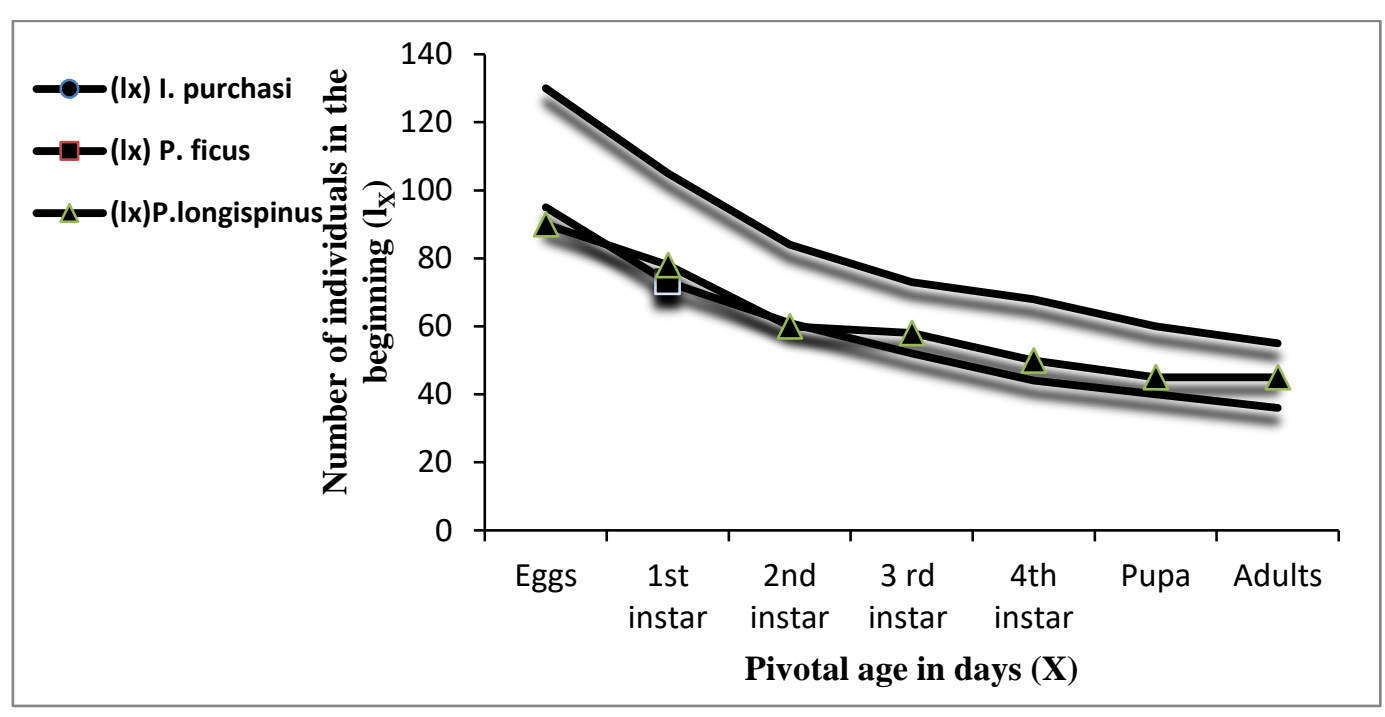


Fig. (1): The age-stage specific survival rates of Rodolia cardinalis on three different mealybugs.

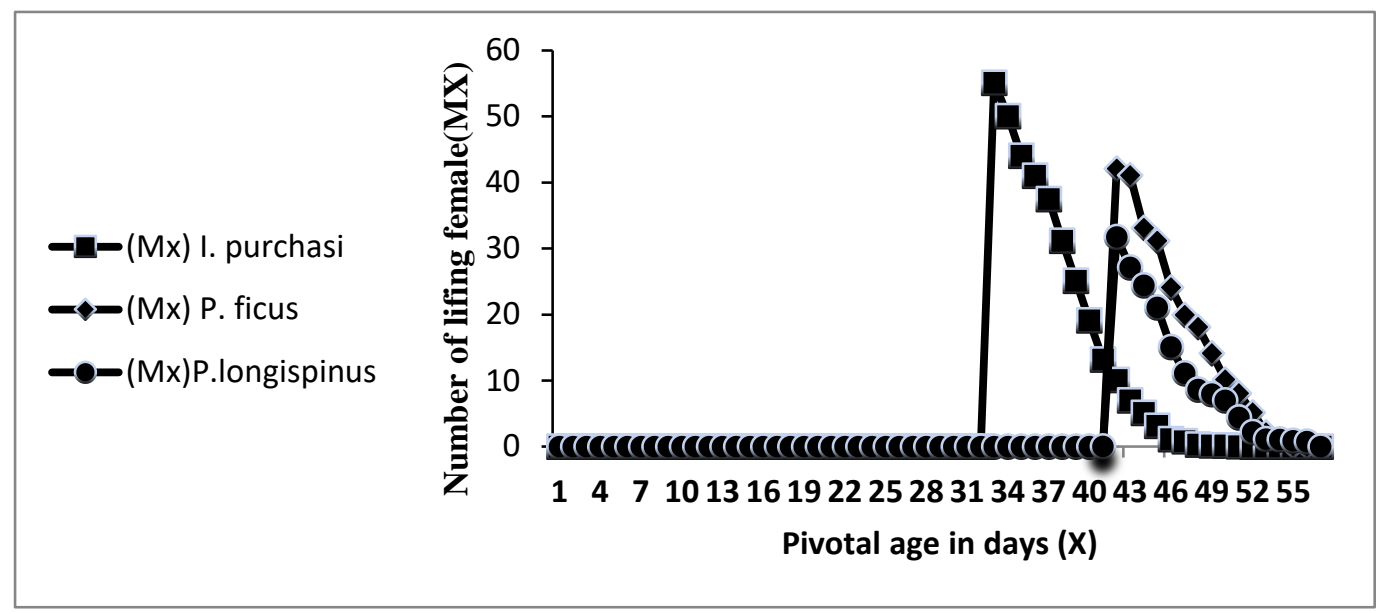

Fig. (2): The female fertility of Rodolia cardinalis on three different mealybugs.

According to the results obtained, the first adult female was recorded on the day (22, 30 and 38), and early egg-laying was also recorded after $(11,12$ and 4$)$ day after the emergence of adult females and the laying of eggs for those females continued almost until death. Concurrently, the results also recorded the first death of female adult predator in the day (53, 56 , and 57) on the three species of mealybug $I$. purchasi, $P$. ficus, and P. longispinus on respectively. The last female of $R$. cardinalis died on day (55, 61 and 64). Furthermore, results in Table (4) showed that the preovipositional period of $R$. cardinalis continued about 10, 11.01, and 3.11 days; ovipositional period continued about 18,12 and 13 days; and post-ovipositional period continued about 4,8 and 10 days on three mealybug species $I$. purchasi, $P$. ficus and $P$. longispinus respectively.

Table (4): Reproduction and longevity of Rodolia cardinalis feeding on three different mealybugs

\begin{tabular}{cccc}
\hline Parameter & I.Purchasi & P.Ficus & P.Longispinus \\
\hline Pre.oviposition period & $10 \pm 0.21$ & $11.01 \pm 0.34$ & $4 \pm 0.15$ \\
Oviposition period & $18 \pm 0.11$ & $12 \pm 0.22$ & $13 \pm 0.17$ \\
Post- Oviposition period & $4 \pm 0.13$ & $8 \pm 0.52$ & $10 \pm 0.48$ \\
Fecundity & $334.94 \pm 0.55$ & $250.94 \pm 0.17$ & $165 \pm 0.03$ \\
Female longevity & $55 \pm 0.07$ & $61 \pm 0.13$ & $64 \pm 0.17$ \\
\hline
\end{tabular}

The results in Table (4) had also supported that the highest fecundity of $R$. cardinalis (334.94 eggs/female) of $R$. cardinalis were registered when nutrition on I. purchase. The results obtained showed that he fully agreed with Ghanim et al. (2006) proved that the favorite 
prey for $R$. cardinalis was I. purchasi compared with the other prey types of mealybug, such as Planococcus citri (Risso) and Icerya seychellarum (Westwood), this is due to the growth of the predator and the completion of its life cycle in a short period, in addition to increasing its predation capacity and reproductive efficiency when feeding on the $I$. purchasi ,thus this predator can be used efficiently as a biological control agent for this mealybug specie.

Figure (2) shows that in general, in the first days of ovulation, the largest number of eggs laid by the adult females predator, while the least numbers of eggs were laid in the last days of the life of those females.

Numerous researchers have proven that the degree of fertility, pre-oviposition, oviposition, postoviposition time, and life span of many predatory insects (Coleoptera: Coccinellidae) is greatly affected by the types of mealybug that feed on them. Baskaran et al. (2002) demonstrated that the host mealybug species had the main impact on pre-oviposition, oviposition, postoviposition periods of $C$. montrouzieri, Zhen-Qiang Qin et al. (2014) registered the highest fecundity of $C$. montrouzieri on Ferrisia virgata Cockerell. between 3 various hosts mealybug species.

The current study confirmed that many important biological characteristics such as growth rates, fertility, and life table factors for the vedalia beetle, R. cardinalis were greatly affected by the species of mealybug raised on them. The fundamental rate of increase (r) and Limited rate of increase $(\lambda)$ of the R. cardinalis bred on three mealybug species were remarkably various.

Table (5) indicated that the population and venereal parameter of $R$. cardinalis. The fundamental rate of increase (r) was the highest in populations bred on I. purchasi (0.14). The varied (r) between the three mealybug species I. purchasi, P. ficus and P. longispinus, it is likely that due to the separate groupings of $R$. cardinalis that are spread in different regions of the world as well as to the differences between the types of mealybug that they prey on (Caltagirone and Doutt (1989), Grafton (2005) and Ghanim et al., 2006). As the same, the highest final reproduction value (Ro) was also noticed on I. purchasi (139.98).

Table (5): Life table parameters of vedalia beetle, Rodolia cardinalis feeding on three different mealybug

\begin{tabular}{cccc}
\hline Parameters & I. purchasi & P. ficus & P. longispinus \\
\hline $\mathrm{R}_{0}$ & 139.98 & 81.10 & 37.70 \\
$\mathrm{~T}$ & 35.85 & 44.71 & 44.03 \\
$\mathrm{r}$ & 0.14 & 0.09 & 0.08 \\
$\lambda$ & 1.15 & 1.11 & 1.08 \\
$\mathrm{D}_{\mathrm{T}}$ & 4.95 & 6.93 & 8.66 \\
$\sum \mathrm{M}_{\mathrm{x}}$ & 334.94 & 250.94 & 165.00 \\
\hline
\end{tabular}

Results in Table (5) also displayed that the time needed to double the population (DT) was registered (4.95, 6.93 and 8.70$)$ on three mealybug species $I$. purchasi, $P$. ficus and $P$. 
longispinus respectively, which proved the great influence of the food type. The results also determined that the vedalia beetle preferred feeding on I. purchasi compared with $P$. ficus and P. longispinus. Generation length rate $(\mathrm{T})$ presented an obvious variation in vedalia beetles bred on the diverse steward mealybug species. The longest generation length rate $(\mathrm{T})$ was established on vedalia beetles breed on $P$. ficus and $P$. longispinus, but the shortest generation length rate was noticed in vedalia beetles rearing on $I$. purchasi. Concerning the gross procreation rate of females, it has amounted to the highest $(\Sigma \mathrm{mx})$ around 334.94 on I. purchasi mealybug.

A lot of the studies carried out on life table transactions are used as important references when selecting the most effective biological control elements in integrated control programs for many pests (Lee, 2002). Usually, it is preferable to choose the biological enemies with the greatest fundamental rate of increase (r) in the absence of other standards (Kontodimas et al., 2007). Several previous studies were conducted on the life tables of $R$. cardinalis in different regions of the world and under various environmental conditions (Cuaston et al. (2004), Ghanim et al. (2006), and Abdel-Salam et al. (2013)

\section{Conclusions}

Life tables are a very important method in assessing the performance of natural enemies in controlling many pests under different weather conditions and in different regions. The current study provided many results and valuable information that seriously contribute to helping in the effective control of the types of mealybugs by $R$. cardinalis predator. The various capability of evolution, stay alive and proliferation of $R$. cardinalis nutrition on the three mealybugs $I$. purchasi, $P$. ficus, and $P$. longispinus recommend that this predator could be chosen as an active biocontrol factor for these three types, particularly in the Integrated control program of $I$. purchasi. The results of the study also showed the possibility of raising the natural enemy, $R$. Cardinalis successfully and in large numbers on many types of mealybugs. The study of the releasing processes of many natural enemies and their effect on controlling many different pests under different environmental conditions factors is a fertile field for further research and study in the future.

\section{References}

Abdel-Salam, A.H., Ghanim, A.A. and Awadalla, H. S.S. (2010) 'Biological attributes and life table parameters of Nephus includens (Kirsch) (Coleoptera: Coccinellidae) as a natural enemy of margarodid mealy bugs in Egypt', Journal of Plant Protection and Pathology, 1 (1): pp. 51-62.

Abdel-Salam, A.H., Ghanim, A.A., El-Kady, H.A., El-Nagar, M.E. and Awadalla, H. S.S. (2013) ' Influence of constant temperature degrees on the biological characters and predacous efficiency of the predator Rodalia cardinalis (Mulsant) ', Journal of Plant Protection and Pathology, Mansoura Mansoura University, 4 (3): pp. 317-324.

Abd-Rabou, S. (2001) 'Parasitoids attack mealybug (Homoptera: Coccidae: Pseudococcidae) in Egyptian', Journal of Agricultural Research, 79 (4): pp. 13551377.

Afifi, A. I., EI-Arnaouty, S. A., Attia, A. R., and Alla, A. EL-M. A. (2010) 'Biological control of Citrus Mealybug, Planococcus citri (Risso) using Coccinellid predator, Cryptolaemus montrouzieri Muls', Pakistan Journal of Biological Sciences, (13): pp. 216-222. 
Ali, A. and Rizvi, P.Q. (2009) 'Life table studies of Menochilus sexmaculatus Fabr. (Coleoptera Coccinellidae) at varying temperature on Lipaphis erysimi Kalt. ', World Applied Science Journal, (7): pp. 897-901.

Awadalla, H. S. S. (2010) ' Studies on biological and life tables parameters of certain predacious insects which associated with some mealybugs', M. Sc. Thesis, Fac. Agric., Mansoura Univ. pp. 125.

Baskaran, R. K. M., Lakshmi, L. G. and Uthamasamy, S. (1999) ' Comparative biology and predatory potential of Australian ladybird beetle (Cryptolaemus montrouzieri) on Planococcus citri and Dactylopius tomentosus', Indian Journal of Agricultural Sciences, (69): pp. 605606.

Baskaran, R. K. M., Srinivasan, T. R., Muthumeena, K., Muthulakshmi, S. and Mahadevan, N. R. (2002) ' Lifetable of Australian ladybird beetle (Cryptolaemus montrouzieri) feeding on mealybugs (Maconellicoccus hirsutus and Dactylopius tomentosus) ', Indian Journal of Agricultural Sciences, (72) pp.54-56.

Caltagirone, L.E., Doutt, R.L. (1989) ' The history of the vedalia beetle importation to California and its impact on the development of biological control', Annual Review of Entomology,(34) pp. $1-16$.

Cuaston, C. E., Lincango, M. P. and Poulsom, T. G. A. (2004) ' Feeding range studies of Rodollia cardinalis (Mulsant), a candidate biological control agent of Icerya purchasi
Maskell in the Galapagos Islands', Biological control, 29(3): pp. 315 325.

Esfandiari, M. and Mossadegh, M.S. (2007) 'Spatial distribution and sampling of Icerya purchasi Mask. (Hom: Margarodidae) on orange trees in South West Iran', Journal of Biological Sciences, 7 (7): pp. 1239-1243.

Ghanim, A. A, Hala, A. K. E. and Nadia, E. M. (2006) ' Effect of mealybug species as preys on the developmental time, feeding capacity and fecundity of vedalia beetle, Rodolia cardinalis (Mulsant) (Coleoptera: Coccinellidae) under laboratory conditions', Journal of Agricultural Science, Mansoura University, 31 (3): pp.1679 -1687.

Grafton, E. E., Gu, P. and Montez, G. H. (2005) ' Effect of temperature on development of vedalia beetle, Rodollia cardinalis (Mulsant)', Biological control, (32): pp.473 - 478.

Kairo, M.T.K. and Murphy, S.T. (1995) 'The life history of Rodolia iceryae Janson (Col., Coccinellidae) and the potential for use in innoculative releases against Icerya pattersonii Newstead (Hom., Margarodidae) on coffee', Journal of Applied Entomology, (119): pp. 487-491.

Kindlmann, P., Yasuda, H., Sato, S. and Shinya, K. (2000) 'Key life stages of two predatory ladybird species (Coleóptera: Coccinellidae)', European Journal of Entomology,(97): pp. 495 499.

Kontodimas, D. C., Milonas, P. G., Stathas, G. J., Economou, L. P., and Kavallieratos, N. G. (2007) ' Life table parameters of the pseudococcid 
predators Nephus includens and Nephus bisignatus (Coleoptera: Coccinelidae)', European Journal of Entomology, (104): pp. 407-415.

Lee, J. H., Lee, K. S. and Lee, H. P. (2002) ' Life table descriptions of Tetrastichus sp. (Hymenoptera: Eulophidae) on Hyphatria cunea Drury', Korean Journal of Biological Sciences, 6(1): pp. 19-22.

Lucas, É., Coderre, D. and Vincent, C. (1997)' Voracity and feeding preference of two aphidophagous coccinellids on Aphis citricola and Tetranychus urticae', Entomologia Experimentalis et Applicata,( 85): pp. 151-159.

Michaud, J.P. (2003) ' A comparative study of larval cannibalism in three species of ladybird', Ecological Entomology (28): pp.92- 101.

Mohamed, N. E. (2013) ' Effect of constant temperature degrees on certain biological characterstics of the coccinellid predator rodolia cardinalis (Mulsant) (Coleoptera: Coccinellidae) ', Journal of Plant Protection and Pathology, Mansoura Mansoura University, 4 (10): pp. $845-855$.

Obrycki, J.J. and Hring, T.J. (1998) Predaceous Coccinellidae in biological control', Annual Reriew of Entomology, (43): pp. 295-321.

Ozgokce, M. S., Atlihan, R., and Karaca, I. (2006) ' The life table of Cryptolaemus montrouzieri Mulsant (Coleoptera: Coccinellidae) after different storage periods', Journal of Food,Agriculture and Environment, (4) pp. 282-287.

Ragab, M.E. (1995) ' Adaptation of Rodolia cardinalis (Mulsant) (Col., Coccinellidae) to Icerya aegyptiaca
(Douglas) (Hom., Margarodidae) as compared with Icerya purchasi Mask', Journal of Applied Entomology, (119): pp. 621-623.

Saleh, A.A.A., Ghanim A.A., Mohamed, N. E. and Ali, S.A.M. (2017) ' Relationship between developmental stages of predator Nephus includes (Kisch) (Coleoptera: Coccinellidae) reared on certain mealybug species and the required thermal units', Egyptian Academic Journal of Biological Sciences, 10(7): pp. 31-40.

Schellhorn, N. A. and Andow, D. A. (1999) 'Mortality of coccinellid (Coleoptera : Coccinellidae) larvae and pupae when prey become scarce', Environmental Entomology,( 28): pp. 1092-1100.

Schowalter, T. D. (2011) ' Insect Ecology: An Ecosystem Approach', (Third ed.): Elsevier. pp. 650.

Southwood, T.R.E. (1966) 'Ecological Methods, with particular reference to the study of insect populations', Methuen and Co. Ltd, London. 390 p.

Sturm, M. M., Sterling, W. L. and Hartstack, A. W. (1990) 'Role of natural mortality in boll weevil (Coleoptera: Curculionidae) management programs', Journal of Economic Entomology,( 83): pp. 1-7.

Townsend, M. L., Oetting, R. D. and Chong, J. H. (2000) ' Management of the mealybug, Phenacoccus madeirensis', Proceedings of South Nursery Associate Research Conference, (45): pp.162-166.

Yang, X.B., Zhang, Y.M., Henne, D.C.and Liu, T.X. (2013) ' Life tables of Bactericera cockerelli (Hemiptera: 
Triozidae) on tomato under laboratory and field conditions in Southern Texas', Florida Entomologist, 96 (3): pp. $904-$ 913.

Zhen-Qiang, Q., Bao-Li, Q., Jian-Hui, W., Andrew, Cuthbertsonc, G.S. and Shun-
Xiang, R. (2014) ' Effects of three mealybug species on the development, survivorship and reproduction of the predatory lady beetle Cryptolaemus montrouzieri Mulsant', Biocontrol Science and Technology, 24(8): pp. 891-900. 